\title{
An experimental approach for studying the genetic and physiological background of nutrient transformation in cattle with respect to nutrient secretion and accretion type
}

\begin{abstract}
Summary
Identifying the genetic and physiological background of phenotypic variability between animals of different nutrient turnover is a well recognised prerequisite for efficient breeding strategies. Published results relevant for our recently initiated project on properties of the nutrient transformation in cattle with respect to secretion type and accretion type are reviewed. For a deeper insight into the genetic and physiological background of both types, an experiment has been initiated using segregating $F_{2}$ offspring's of crosses of Charolais bulls and German Holstein cows. It will be shown that, with respect to their phenotypic and physiological properties, these two breeds are especially suitable for a study of the accretion and secretion type. The basis of the experimental design and the intended investigations are described.
\end{abstract}

Key Words: cattle, secretion and accretion type of nutrient turnover, segregating families, QTL, physiology, linkage analysis, experimental design

\section{Zusammenfassung}

Titel der Arbeit: Ein experimenteller Ansatz zur Untersuchung des genetischen und physiologischen Hintergrundes des Nährstoffumsatzes bei Rindern bezüglich des Umsatz- und Ansatztyps

Die Identifizierung der genetischen und physiologischen Grundlagen der Unterschiede zwischen Rindern, die sich im Stoffwechseltyp und somit im Nährstoffumsatz unterscheiden, ist eine anerkannte Voraussetzung für effiziente Zuchtstrategien.

Es wird ein Überblick gegeben über bislang in der Literatur beschriebene Ergebnisse mit Relevanz für vorliegend beschriebenen Versuchsansatz zur Futterverwertung bei Rindern des Sekretions- bzw. Ansatztyps. Um einen tieferen Einblick in die genetischen und physiologischen Grundlagen dieser beiden Verwertungstypen zu erhalten, wird ein Experiment mit segregierenden $F_{2}$ Nachkommen aus einer Kreuzung zwischen CharolaisBullen und Deutsche-Holstein-Kühen durchgeführt. Es wird gezeigt, dass auf Grund ihrer phänotypischen und physiologischen Eigenschaften diese beiden Rassen für die Untersuchung des Sekretions- und Ansatztyps besonders geeignet sind. Die Grundprinzipien der Versuchplanung und der beabsichtigten Untersuchungen werden beschrieben.

Schlüsselwörter: Rind, Stoffumsatz, segregierende Familienstrukturen, QTL, Physiologie, Kopplungsanalyse, Versuchsplan

1.

Introduction

Being primarily selected for either milk or meat production the major cattle breeds in world wide use strikingly differ in their respective phenotype under conditions of German farming systems (ADR report, 1999). Dairy breeds such as Holstein-Friesian are especially apt in secreting main nutrients (protein, fat, carbohydrates) partly derived from their diet in milk. Generally, such breeds are categorised as the secretion or dairy type. In contrast, beef cattle such as the Charolais breed are characterised by their ability to accrete synthesised substance as meat, therefore they are categorised as 
accretion or meat type. The reasons why ruminants transform feed components preferentially either in body tissues or milk are not completely understood. Especially, the factors explaining the differences in a type of body mass accretion (fat vs. protein) remain to be established. Furthermore, the factors explaining the differences in type of body mass accretion (fat vs. protein) remain to be established. The degree of fat or protein accretion can differ substantially between and within dairy and meat type breeds. It is of prime importance to know the reasons for different nutrient transformation because feed efficiency largely depends on it within a desired production scheme.

Identifying the genetic and physiological background of the differences between animals with different nutrient turnover is a well recognised prerequisite for efficient breeding progress. Putative reasons for genetic differences between animals might relate to the extent and site (rumen or intestine) of digestion and absorption rates of nutrients as well as in the nutrient partitioning in various body tissues. Current knowledge on the principles of metabolic control of nutrient transformation is given in section 2.

So far, systematic characterisation of metabolic types was limited to a descriptive level only. However, the multifactorial, interactive regulation of nutrient transformation requires an innovative complex analysis of nutrient transformation in the accretion and the secretion metabolic type comprising a profound genetic and physiological investigation of relevant traits. Thus, it is desirable to generate a complex design for combining genetic, physiological and biochemical parameters to provide a better understanding of the underlying causative mechanisms.

To create a suitable experimental animal model for the genetic and physiological investigations, an $\mathrm{F}_{2}$ resource family was designed by crossing Charolais bulls and German Holstein cows differing significantly in accretion and secretion. Reasons for selecting Charolais and German Holsteins as representatives of both metabolic type are outlined in section 3 .

Detailed genetic and molecular analysis of diversity in nutrient transformation requires assignment of genetic variability to defined chromosomal regions and genetic elements. In our project this will be achieved by detection of co-segregation between a genetic locus of known genomic position and traits of nutrient transformation in an $\mathrm{F}_{2}$ resource population. Principles of the $F_{2}$ design for genetic investigation and their application for the set-up of our $F_{2}$ population as well as a calculation of required $F_{2}$ population size are given in section 4 .

The described experimental set-up to study the genetic background of the nutrient transformation is unique with respect to the traits included. However, the simultaneous investigation of the physiological bases of nutrient transformation in the $F_{2}$ individuals additionally represents an innovative approach for physiological investigations. The progress to be achieved by application of this $F_{2}$ design in cattle compared to previous studies investigating interbreed differences is outlined in section $4 \mathrm{~b}$.

Genetic differences in partitioning and utilisation of nutrients and nutrition-gene interactions seem to be main factors for differences in metabolic type of ruminants 
(BAUMAN and CURRIE, 1980; CRONJÉ, 2000). The genetic influence on metabolism ranges from single gene effects on amino acid sequence of protein to quantitative genetic effects on functional proteins like enzymes, transporters, hormones or receptors (KIDDY, 1979).

Growth, lactation and metabolism are controlled by multiple hormones and factors acting in an endocrine (systemic) and an autocrine (local) manner (CANT et al., 1999; BREIER et al., 2000). Both endocrine and autocrine mechanisms control the partitioning of absorbed nutrients between various body tissues and organs. The control takes place at two levels: homeostasis and homeorhesis (BAUMAN and CURRIE, 1980).

Homeostasic control ensures the maintenance of the physiological steady state in the internal environment, e.g. the physiological level of glucose in blood. The short-term control of blood glucose levels is achieved by the contrary actions of pancreatic hormones (insulin, glucagon) in response to glucose uptake, production and utilisation in several organs and tissues. The mechanism involves variability of set-points for physiological responses of several organs. Such variability of a set-point could be generated by the response of a tissue receptor to a hormone. The hypothesis of a shift in nutrient partitioning in animals differing in metabolic type involves alterations in the set-points of physiological response to homeostatic control. For example, CRONJÉ et al. (1999) demonstrated that the insulin-secreting cells of the pancreas were less sensitive to circulating concentrations of blood glucose and skeletal muscle and adipose tissues were less sensitive to insulin in Saanen cross-breed goat (milk type goat) than in indigenous goat (meat type). Differences in insulin receptor concentrations have been observed in different breeds of sheep as well (WYLIE et al., 1998). It was suggested by CHARRON et al. (1999) that the variation in Glucose transporter 4 (GLUT-4) gene expression may be the major determinant of insulin sensitivity in humans. GIESECKE et al. (1987a, b) demonstrated a higher insulin response after i.v. infusion of glucose in fat cows than in normal cows and differences in insulin function between Holstein Frisian cows and German Simmental cows. It can be concluded that genetic variation in nutrient turnover, in part, may be mediated by insulin sensitivity in some tissues.

The homeorhetic control of nutrient partitioning and the physiological process is defined as "the orchestrated or co-ordinated changes in metabolism of body tissues necessary to support a physiological state” (BAUMAN and CURRIE, 1980). Key features of homeorhetic control are: its chronic nature (i.e. hours or days), its simultaneous influence on multiple tissues, and its mediation through altered response to homeostatic signals (BAUMAN and CURRIE, 1980). Lactation demonstrates an example for homeorhetic control. Physiological adaptations during lactation involve many body tissues and all kind of nutrients to support the milk synthesis of the mammary gland. Many hormones and their receptors, the most prominent being growth hormone (e.g. KOBAYASHI et al., 1999), are included in this metabolic control.

The ratio between protein and fat in body gain drops earlier in Holstein cattle in comparison to Charolais cattle (INRA, 1988, AfB, 1995). This indicates a different partitioning of nutrients and energy for fat and protein synthesis, given that the individuals from the two different breeds consume nearly the same amount of feed. The somatropic axis and insulin can be considered to be important for nutrient 
partition as reviewed by BREIER and SAUERWEIN (1995). The somatotropic axis co-ordinates the genetic potential to grow and regulates adaptive processes according to nutritional conditions. Other hormones, like insulin and thyroid hormones, are involved in the regulation of the growth process. Generally, trijodothyronine and insulin plasma levels are positively and growth hormone $(\mathrm{GH})$ is negatively related to adiposity development (HOCQUETTE et al., 1999; CLINQUART et al., 1995). Although hormone concentrations differed with bull breed (German Holstein and Belgian Blue), neither GH nor the Insulin like growth factor 1 (IGF-I) was directly proportional to breed differences in lean muscle growth (ISTASSE et al., 1990). However, BICKERSTAFFE et al. (1994) showed that lambs with a minor response to insulin after glucose load indicated a higher $\mathrm{GH}$ level after infusion of the $\mathrm{GH}$ releasing factor $(\mathrm{GHRH})$. These lambs exhibited less fat and more protein in the carcass compared to lambs with a greater response to insulin, which suggested a modified distribution of the nutrients. Recently, CONNOR et al. (1999) observed a positive relationship between $\mathrm{GH}$ response to $\mathrm{GHRH}$ and weight gain along with an inverse relationship between $\mathrm{GH}$ response and body fat in Angus bulls. The relationship between plasma IGF-I and growth rates in cattle seems to be variable (CONNOR et al., 2000).

Model calculations indicate that the energy requirement of German Holstein bulls for growth (1150 g daily gain) is significantly higher compared to energy requirement of Charolais bulls (CHUDY, 1999, personal communication). Growing cattle partition their energy intake between requirements for maintenance and requirements for accretion. Both factors can be influenced by breed (FERREL and JENKINS, 1998) and have be evaluated separately. TAYLOR et al. (1986) found differences in energy requirement for maintenance between heifers of beef and milk breeds like Hereford, Aberdeen Angus, Dexter, British Friesian and Jersey. The maintenance energy requirement of the milk type breeds was about $20 \%$ higher in comparison to beef type breeds. Different sympathetic nervous system activity could be a reason for this phenomenon (DERNO et al., 1998). As a second factor, interactions between the nutrients are probably of importance as well. Animals which are able to mobilise body fat as an energy source for protein synthesis could be more efficient in protein utilisation (CHOWDHURY et al., 1997).

\section{Charolais and German Holstein as representatives of the accretion and secretion type}

By using extreme types of cattle for establishing an $\mathrm{F}_{2}$ resource family the maximum phenotypic variation is introduced into a large number of traits including lactation, growth, carcass composition, and meat quality, as well as physiological characteristics. Breeding for special yield characters inherently changes the regulation of the animal body. Mechanisms of genetic regulation are affected, so mechanisms of endocrine functions are also influenced (MÜLLER et al., 1999). The reasons why ruminants transform feed components preferentially in body mass or milk are largely unknown. By characterising physiological parameters of defined metabolic pathways and their interaction with traits related to growth, carcass composition, and milk yield, a profound analysis of bovine nutrient transformation becomes possible. 


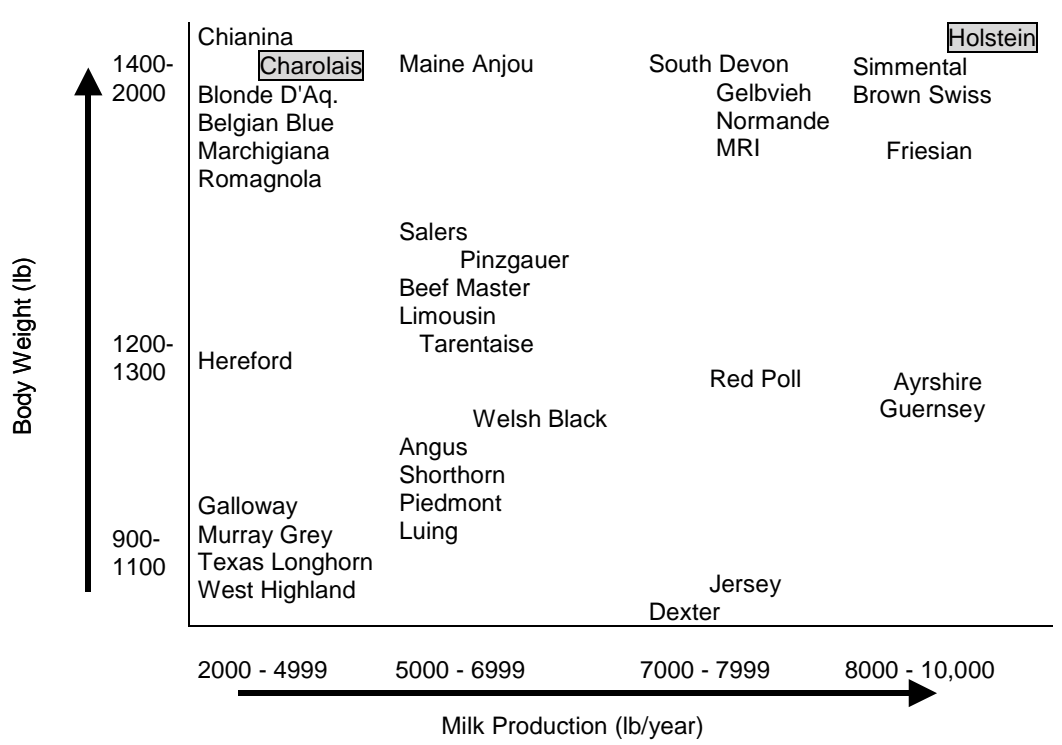

Fig. 1: Cattle breeds distributed by body weight and milk production (Verteilung von Rinderrassen nach Körpergewicht und Milchleistung)

German Holstein as dairy breed and Charolais as beef breed were selected for the following reasons: the two breeds should be of significant economical importance, they should be of similar size and maturing age, and finally they should differ as much as possible concerning the final products, e.g. milk or meat. In other words, they should fit either the secretion or the accretion type. Two figures (Fig. 1 and Fig. 2, please pay attention to the non-metric units) from the Alberta State government in Canada (http://www.agric.gov.ab.ca/livestock/beef/breeds1.html) demonstrate, that German Holstein and Charolais are suitable breeds to achieve the goals of our study. The figures demonstrate that the mature weights are very similar in both breeds. Mature weights reached in Holstein bulls about $1090 \mathrm{~kg}$, in Charolais bulls $1136 \mathrm{~kg}$, in Holstein cows $681 \mathrm{~kg}$ and in Charolais cows $795 \mathrm{~kg}$ (GONNEWORDENE, 1996).

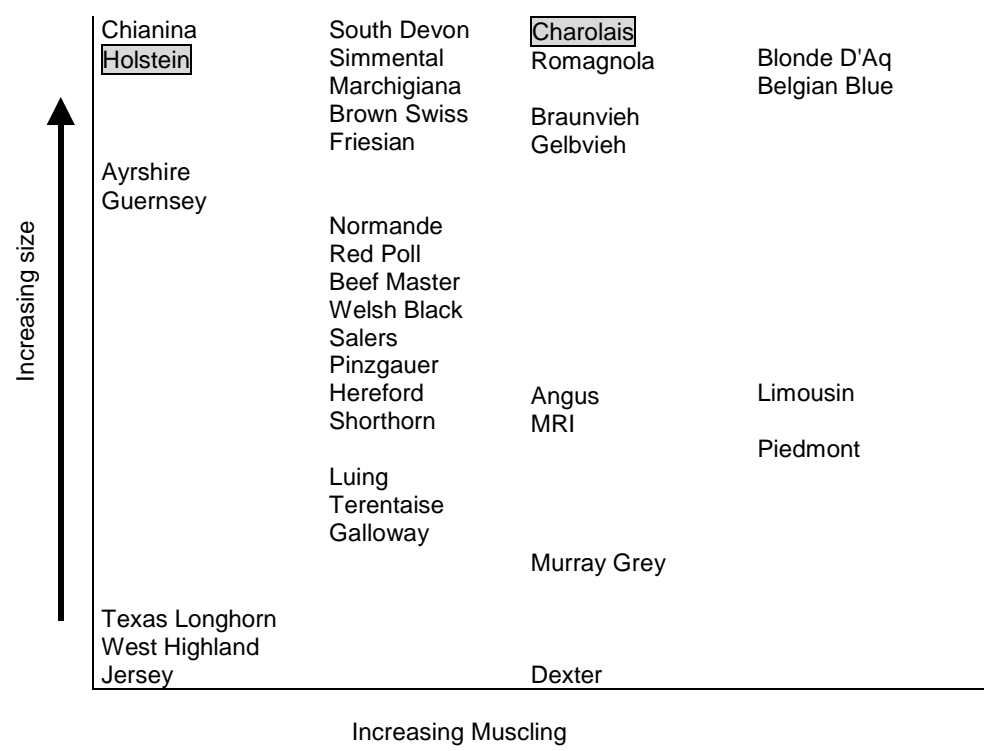

Fig. 2: Cattle breeds distributed by size and muscling (Verteilung von Rinderrassen nach Körpergrösse und Bemuskelung) 
Other breeds seem to be also suitable for the experiment, but they were excluded for certain reasons. In Belgian Blue, growth traits are strongly influenced by the major gene effect of myostatin genotype (GROBET et al., 1997). Worldwide Aberdeen Angus is used as an important beef breed because of their well marbled meat. In European Countries, however, the consumer prefers the more lean meat of Charolais. Also the Aberdeen Angus are of much smaller frame size compared with German Holstein cattle. Similarly, Jersey cattle as another important dairy breed did not fit the requirements because of the small frame size.

Holstein dairy cattle are well-known for their outstanding milk production and distinctive colour patterns of black and white or red and white. World-wide, Holstein are the most frequently bred cattle. The Holstein cow originated in Europe. The historical development of this breed occurred in what is now the Netherlands and more specifically in the two northern provinces of North Holland and Friesland. The German Holstein developed from European Black Pied and American Holstein into Germany's most important dairy breed (SAMBRAUS, 1989).

German Holsteins are bred for high milk production and good growth performance. They are a large framed cattle with mature cows weighing around $750 \mathrm{~kg}$. They are characterised by a genetically determined adaptability to produce milk under diverse environmental conditions, a high forage and dry matter intake capacity. The industry strives for a genetic production capability of more than $8,000 \mathrm{~kg}$ milk at $4.0 \%$ fat and $3.5 \%$ protein. In Germany the 1999 average milk yield of recorded Holstein cows came to 6958 to $7460 \mathrm{~kg}$ with 4.2 to $4.3 \%$ fat and 3.4 to 3.5\% protein (ADR, 1999). The daily weight gain of Holstein bulls resulted in $1.17 \mathrm{~kg}$ (field records) or on testing stations to $1.34 \mathrm{~kg}$ (ADR, 1999). FORREST (1977) stated that Holstein Steers slaughtered at $500 \mathrm{~kg}$ live weight had a hot carcass weight of $268.2 \mathrm{~kg}$, the M. longissimus dorsi contained $3.5 \%$ intramuscular fat, the $\mathrm{M}$. semimembranosus contained $2.52 \%$ intramuscular fat.

Charolais cattle originated in west-central to south-eastern France, in the old French provinces of Charolles and neighbouring Nievre. The French have long selected their cattle for size and muscling. Out of all the beef breeds, Charolais is the greatest population in Germany. Today Charolais is one of the best beef breeds in more than 60 countries. Charolais tops all breeds in nearly every category of performance in the records of beef performance testing organisations in the USA.

For beef cattle the major objective in attempts to influence carcass composition is to have a high proportion of muscle combined with a desired proportion of fat with a minimum amount of bone and feed waste.

ARTHUR et al. (1995) reported Charolais bulls with an average live weight of $613 \mathrm{~kg}$ and a hot carcass weight of $360 \mathrm{~kg}(=58.7 \%)$. The daily weight gain in field-recorded Charolais bulls is with $1.41 \mathrm{~kg}$ higher than in Holstein bulls (ADR, 1999). This value is again higher in testing stations and reached $1.67 \mathrm{~kg}$.

The intramuscular fat depends on the feeding system; 1.7\% using barley, 2.4\% using corn (MANDELL et al., 1997). The 305-day milk yield of Charolais heifers was much lower than in Holstein heifers (1826 to $5256 \mathrm{~kg}$; COLLEAU, 1978).

Holstein and Charolais cattle differ in the growth process and their nutrition accretion. In comparison to Charolais the maximum daily gain was earlier in Holstein cattle and the daily body gain dropped strongly after reaching the maximum gain. From energetic 
feed evaluation systems (INRA, 1988; AfB, 1995) it can be concluded that the energetic requirement for the same body weight gain is significantly higher in German Holstein in comparison to Charolais.

As a hypothesis it can be assumed that the major differences between Charolais and German Holstein regarding many general production parameters originate from differences in nutrient pathway and storage.

Regarding genetic distance between Charolais and Holstein in relation to other European breeds BLOTT et al. (1998) assigned the two breeds to different groups of breeds. Charolais belong to a block of breeds with central European and Mediterranean origin, which also included other French and Italian breeds and the Channel breeds (Jersey, Guernsey). This block of breeds was clearly differentiated from another block of breeds containing e.g. Holstein and Meuse Rhine Ysel, which originated from the northern part of Europe. BLOTT et al. (1998) concluded, that relationships among breeds reflected their geographic origin rather than the agricultural use for which the breeds have been selected.

4.

The $F_{2}$ design for investigation of the basis of divergent nutrient transformation in cattle

\section{$\underline{\text { a. The } F_{2}}$ design for genetic investigation}

Genomic localisation and characterisation of genetic variation of complex traits can be investigated by the application of QTL mapping within an $\mathrm{F}_{2}$ design (LANDER and BOTSTEIN, 1989; PATERSON et al., 1991; ANDERSSON et al., 1994). Due to the complex character of nutrient transformation for accretion and secretion it can be assumed that this experimental approach will be informative for these traits, as well. Assignment of genetic variation to distinct genomic regions is a prerequisite for identification of trait associated genes and gene variants being expressed in tissues of major relevance for an animals metabolic type. Numerous examples in plant, human, mice and livestock species demonstrated the power of this approach to identify the genetic background of complex traits [TAI et al., 1999 (tomato); EVERETT et al., 1997 (human); PETERFY et al., 2001 (mouse); GROBET et al., 1997 (cattle)]. The detailed description of phenotypic traits as it has been shown for the identification of the genetic background of the Rendement Napole (RN) phenotype in pig is crucial for the identification of genetic reasons for phenotypic variability (LEBRET et al., 1999; MILAN et al., 2000). In this respect profound investigation of the physiological background of trait differentiation will complement its genetic analysis.

Observation of co-segregation between a genetic locus of known genomic position and the trait of interest is a key requisite to map genetic loci with impact on a quantitative trait (QTL). Genetic variability of the target trait is obligatory for segregation in a resource population for QTL mapping. By mating individuals of two breeds $\left(\mathrm{P}_{0}\right)$ with large differences concerning the target trait a parental $\mathrm{F}_{1}$ generation can be produced with high heterozygosity at QTL with impact on the target trait. This has been widely exploited in QTL mapping by the construction of $\mathrm{F}_{2}$ designs between breeds or lines yielding high genetic variance (PATERSON et al., 1990/1991; ANDERSSON et al., 1994). Dairy and meat cattle breeds like German Holstein and Charolais represent such lines differing considerably regarding nutrient metabolism. Due to long term 
selection for dairy or meat production, respectively, these breeds are assumed to carry alternative alleles at QTL with impact on secretion or accretion. However, QTL mapping experiments within Holsteins, a heavily selected dairy breed, show that QTL with strong effect on milk production still segregate within this breed (GRISART et al., 2002; KÜHN et al., 1999). While for inbred lines pedigree structure of the $F_{2}$ design has no impact, QTL mapping in an $\mathrm{F}_{2}$ design from outbred breeds with no fixed QTL alleles has the strongest power when family sizes are large (ALFONSO and HALEY, 1998). In cattle this can be achieved by extensive use of superovulation and embryo transfer to generate $F_{1}$ and $F_{2}$ generation. When several $P_{0}$ parents are included, rotational mating in the $\mathrm{F}_{1}$ generation can avoid inbreeding thus reducing unwanted effects in the $F_{2}$ individuals of either general inbreeding and of homozygosity at recessive deleterious loci.

\section{b. The $\mathrm{F}_{2}$ design for physiological investigation}

The use of the $\mathrm{F}_{2}$ design is well established for genetic investigation of complex traits. Thus, this design can also be applied for the physiological investigation of complex traits like divergent nutrient transformation. Physiological investigation of this trait is mainly aimed at the detection of principles resulting in differences of metabolism during growth and lactation. When environmental conditions in the resource population are kept constant, differences in secretion and accretion should reflect differences of divergent metabolic regulation. However, investigations for diverging regulative principles between breeds/lines may be misleading due to misinterpretation of random fixation of phenomena within one breed/line. When assuming two random unlinked traits (e.g. coat colour and milk production) with extremely different distributions in two populations, any analysis across these populations will show association of the traits irrespective of true relationship. In an $F_{2}$ design, however, intercross mating will disrupt this disequilibrium of unlinked traits. Therefore, the segregating $F_{2}$ individuals will enable investigation of distinct metabolic types compared to previous investigation of different outbred lines.

While the genetic investigations focus on detection of the background for trait diversity at the DNA and RNA level the physiological investigations include analysis of the physiological principles for trait performance on the level of nutrient transformation in cattle of different metabolic type. For refined characterisation of metabolic processes, determination of events in protein synthesis and lipid metabolism characteristic for the respective metabolic types and related to parameters of the energy metabolism with special reference in muscle will add further knowledge. Determination of nutrient and energy accretion in relation to expenditure of metabolisable energy in genetically different metabolic types will provide knowledge about nutrient pathways and their regulation.

\section{c. Sample size and structure of the initiated $\mathrm{F}_{2}$ design}

Generally, QTL detection requires larger sample sizes than estimation of correlation coefficients between physiological traits. Therefore, calculation of power or necessary sample size can be restricted to the demands of QTL detection. We focus our interest on those QTL with fixation of alternative QTL alleles $Q_{1}$ and $Q_{2}$ in the parental lines. 
The genotypic effects of the three QTL genotypes $\left(Q_{1} Q_{1}, Q_{1} Q_{2}, Q_{2} Q_{2}\right)$ in the resulting $\mathrm{F}_{2}$ are set at $a, d$, and $-a$ respectively, where $a$ denotes the additive effect and $d$ the dominance deviation (FALCONER and MACKAY, 1996).

In real data QTL mapping experiments, significance thresholds have to be determined which are specific for the respective experiment. In many regression analyses a permutation procedure (CHURCHILL and DOERGE, 1994) was used for this purpose. For generating the design of our experiment however, we applied a simulation method developed by GUIARD and TEUSCHER (submitted), assuming that the QTL and the markers considered are alternatively homozygous in both parent breeds/lines. For samples of $500 \mathrm{~F}_{2}$ generation individuals we simulated the genotypes of 6 markers per chromosome in $20 \mathrm{cM}$ intervals and the phenotype under the null hypothesis of no QTL. Since we are interested in cattle we assumed 30 chromosomes. For every $1 \mathrm{cM}$ position along the chromosome an $F$-statistic was calculated according to the regression method of HALEY and KNOTT (1992) and the maximum, $F_{\max }$, of these $F$-values was determined. In order to get an approximation of the asymptotic distribution of $F_{\max }$ we repeated this simulation 1000 times. Requiring a genome wide risk of $\alpha_{\text {genome }}=0.05$, we found, that the threshold $T=8.73$ fulfils the condition $\operatorname{Pr}\left(F_{\max }>T\right)=0.05$.

As an alternative hypothesis we assume that a QTL exists on a random position within a marker interval with $\operatorname{var}_{\mathrm{QTL}} \%=6 \%$, where $\operatorname{var}_{\mathrm{QTL}} \%$ denotes the portion of the phenotypic variance of the $\mathrm{F}_{2}$ generation explained by the QTL. For this QTL the mean power, calculated as the mean of all power values over the marker interval, is required to be $80 \%$. If $d_{\text {rel }}=d / a$ denotes the relative dominance, then using the method of GUIARD and TEUSCHER, for $T=8.73$ and $\operatorname{var}_{\mathrm{QTL}} \%=6 \%$ the necessary $\mathrm{F}_{2}$ sizes $N$ are shown in the Table.

Table

Necessary $F_{2}$ sample sizes $N$ and corresponding additive effects for $T=8.73$, $\operatorname{var}_{\mathrm{QTL}} \%=6 \%$, mean power $80 \%$ and different values of relative dominance $d_{\text {rel }}=d / a$

\begin{tabular}{llll}
\hline$d_{\text {rel }}$ & 0 & 0.5 & 1 \\
$\mathrm{~N}$ & 443 & 451 & 467 \\
$a^{1}$ & 0.346 & 0.327 & 0.283 \\
\hline
\end{tabular}

${ }^{1}$ in phenotypic standard deviations in $\mathrm{F}_{2}$

For a given significance threshold, power, and proportion of phenotypic variance explained by the QTL, the sample size $N$ also depends on $d_{\text {rel }}$. For a given sample size of $N=460$ the mean power can be calculated with respect to $\operatorname{var}_{\mathrm{QTL}} \%$. The result is shown in Figure 3.

According to the Table in our experiment the main focus will be on traits with an additive effect $a$ of at least $0.34 \sigma_{F_{2}}$. Since within the parental generation the phenotypic standard deviation $\sigma_{P_{0}}$ is smaller than $\sigma_{F_{2}}$, the quotient $a / \sigma_{P_{0}}$ should exceed 0.34. For our family design we target at $a / \sigma_{P_{0}}$ requiring a relative mean difference $2 a / \sigma_{P_{0}}$ between the parental lines greater than 0.8 . 
The intended mating structure of the experiment is shown in Figure 4. As a first step, within every $F_{2}$ family 20 animals will be produced. As a second step, 3 families selected with respect to fertility and high phenotypic variance will be extended to 140 animals.

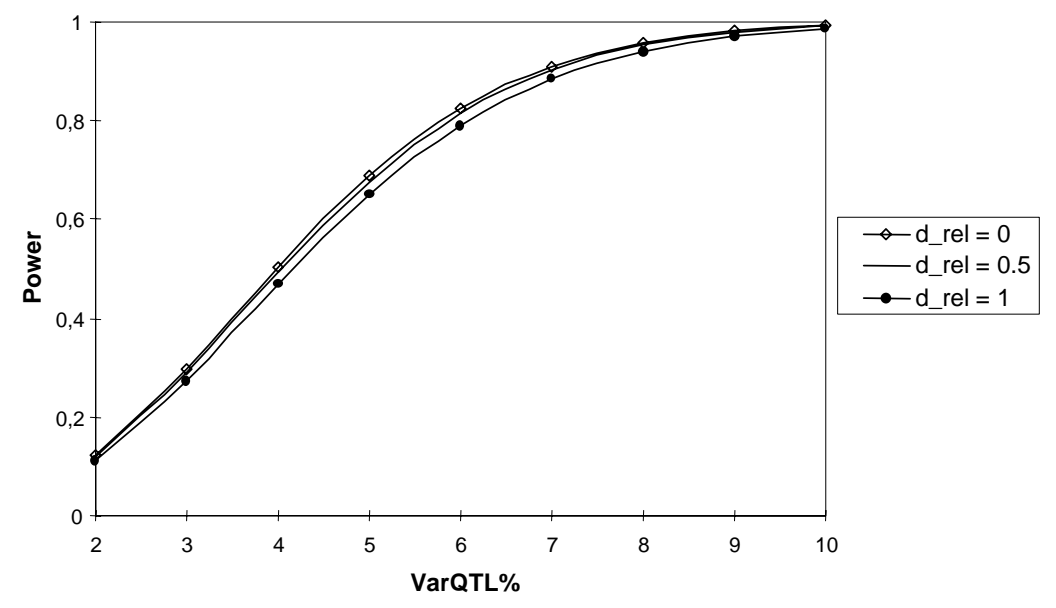

Fig. 3: Mean power for $\mathrm{N}=460, d_{\text {rel }}=d / a=0, d_{\text {rel }}=0.5$, and $d_{\text {rel }}=1$ in dependence on $\operatorname{var}_{\mathrm{QTL}} \%$ (Mittlere Power bei $\mathrm{N}=460, d_{\text {rel }}=d / a=0, d_{\text {rel }}=0.5$, und $d_{\text {rel }}=1$ in Abhängigkeit von $\operatorname{var}_{\mathrm{QTL}} \%$ )
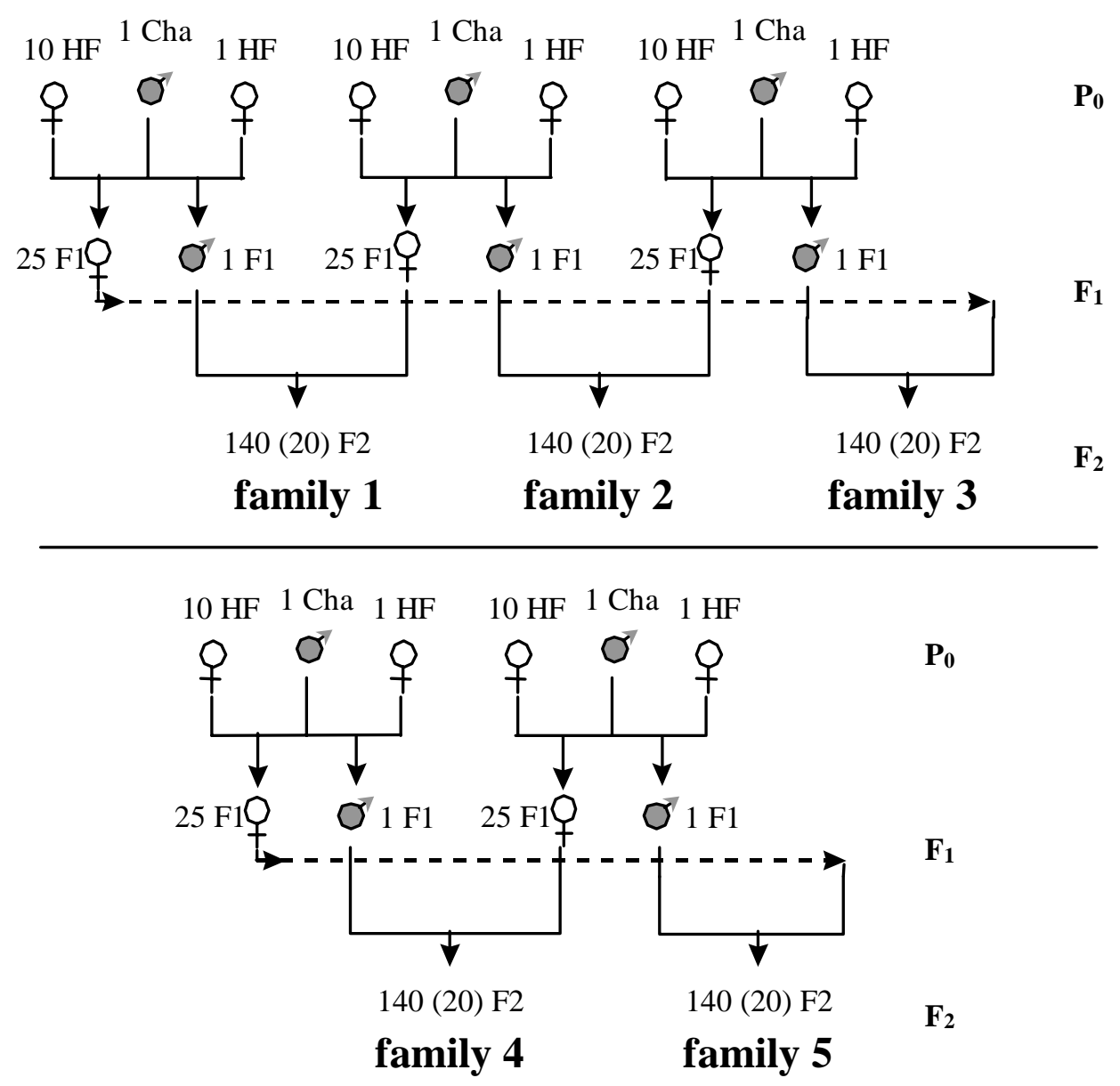

Fig. 4: Intended mating structure (Vorgesehene Anpaarungsstruktur) 
After genotyping an initial set of markers per chromosome (1 per $20 \mathrm{cM}$ ), for all positions on the genome, the information content (e.g: KNOTT et al., 1998) will be calculated. Further markers will then be genotyped until the information content for all positions is at least 0.7-0.8.

\section{Implications for cattle breeding}

The localisation and characterisation of genetic variation regarding nutrient accretion and secretion can provide basic fundamentals for targeted breeding management by marker assisted selection, e.g. marker assisted introgression of desirable alleles into a breed (KOUDANDE et al., 2000). The development of trait-associated expression profiles would allow insights in the physiological basis of trait performance and differentiation. These expression profiles could then supplement physiological investigation and serve as a scalable measurement for assessment of physiological status of an individual by transcript profiling.

The results expected to be generated by this comprehensive genetic and physiological approach will contribute to a novel understanding of the genetic as well as physiological basis of nutrient transformation of both accretion and secretion. Information about the localisation and character of chromosomal regions and genes with impact on nutrient transformation will be generated, which is lacking up to now. This knowledge will indicate metabolic pathways, which should be targeted by physiological investigations to detect mechanisms involved in variability of nutrient transformation. A physiological investigation of metabolic types instead of pure breeds will eliminate the problem of linkage disequilibrium between unlinked traits and therefore allow well-proven conclusions about physiological pathways and regulative processes relevant for divergent nutrient transformation. By choosing breeds with major importance in European animal production and environmental conditions analogous to German farming conditions results obtained in this study will be suitable for transfer into practical applications.

\section{References}

ADR report, ARBEITSGEMEINSCHAFT DEUTSCHER RINDERZÜCHTER:

Rinderproduktion in Deutschland, 1999

AfB,

Energie- und Nährstoffbedarf landwirtschaftlicher Nutztiere, Empfehlungen zur Energie- und Nährstoffversorgung der Mastrinder, 1995, DLG-Verlag, Frankfurt (Main)

ALFONSO, L.; HALEY, C.S.:

Power of different $F_{2}$ schemes for QTL detection in livestock. Animal Science 66 (1998), 1-8

ANDERSSON, L.; HALEY, C.S.; ELLEGREN, H.; KNOTT, S.A.; JOHANSSON, M.; ANDERSSON, K.; ANDERSSON-EKLUND, L.; EDFORS-LILJA, I.; FREDHOLM, M.; HANSSON, I.; HAKANSSON, J.; LUNDSTRÖM, K.:

Genetic mapping of quantitative trait loci for growth and fatness in pigs. Science 263 (1994), 1771-1774

ARTHUR, P.F.; HEARNSHAW, H.; JOHNSTON, D.; STEPHENSON, P.D.:

Evaluation of Angus, Charolais and Hereford as terminal sire breeds on Hereford and first-cross cows. II. Carcass characteristics and retail yield of progeny. Aust. J. Agric. Res. 46 (1995), 1231-1244

BAUMAN, D.E.; CURRIE; W.B.:

Partitioning of nutrients during pregnancy and lactation: a review of mechanisms involving homeostasis and homeorhesis. J. Dairy Sci. 63 (1980), 1514 - 1529

BICKERSTAFFE, R.; SUN, Y.X.; KEELEY, G.; BRAY, A.R.:

Insulin, growth hormone, muscle proteases and carcass composition selected for glucose tolerance. Proc. Soc. Nutr. Physiol. 3 (1994), 300 
BLOTT, S.C.; WILLIAMS, J.L.; HALEY, C.S.:

Genetic relationships among European cattle breeds. Anim. Genet. 29 (1998), 273-282

BREIER, H.H.; OLIVER, M.H.; GALLAHER, B.W.:

Regulation of growth and metabolism during postnatal development. In: Ruminant physiology: digestion, metabolism, growth and reproduction. P. CRONJE (Ed.), CAB International, Wallingford, UK, 2000, p. 187 - 204

BREIER, B.H.; SAUERWEIN, H.:

Regulation of growth in ruminants by the somatotropic axis. In: Ruminant physiology: digestion, metabolism, growth and reproduction. W. von ENGELHARDT et al. (Eds.). F. Enke Verlag, Stuttgart, 1995, p. 451 - 474

CANT, J.P.; QIAO, F.; TOERIEN, C.A.:

Regulation of mammary metabolism. In: Protein Metabolism and Nutrition, G. E. LOBLEY, A. WHITE and J. C. MACRAE (Eds.), EAAP Publication No. 96), Wageningen Pers, The Netherlands, 1999, p. 203-219

CHARRON, M.J.; KATZ, E.B.; OLSON, A.L.:

GLUT-4 gene regulation and manipulation. J. Biol. Chem. 274 (1999), 3253-3256

CHOWDHURY, S.A.; ØRSKOV, E.R.; HOVELL, F.D.; SCAIFE, J.R.; MOLLISON, G.:

Protein utilization during energy undernutrition in sheep sustained by intragastric infusion: effects of protein infusion level, with or without sub-maintenance amounts of energy from volatile fatty acids, on energy and protein metabolism. Brit. J. Nutr. 77 (1997), 565-576

CHURCHILL, G.A.; DOERGE, R.W.:

Empirical threshold values for quantitative trait mapping. Genetics 138 (1994), 963-971

CLINQUART, A.; VAN EENAEME, C.; MAYOMBO, A.P.; GAUTHIER, S.; ISTASSE, L.:

Plasma hormones and metabolites in cattle in relation to breed (Belgian Blues vs Holstein) and conformation (double-muscled vs dual-purpose type). Vet. Res. Commun 19 (1995), 185-194

COLLEAU, J.J.:

Comparaison de types genetiques bovins laitiers mixtes ou specialises. La-vache-laitiere. - Aspectsgenetiques,- alimentaires,- pathologiques. Suppl. to Bull. Tech. de Centre de Rech. Zootech. et Vet. de Theix, 1978, 17-29

CONNOR, E.E.; BARAO, S.M.; DOUGLASS, L.W.; ZINN, S.A.; DAHL, G.E.:

Predicting bull growth performance and carcass composition from growth hormone response to growth hormone-releasing hormone. J. Anim. Sci. 77 (1999), 2736-2741

CONNOR, E.E.; BARAO, S.M.; KIMREY, A.S.; PARLIER, A.B.; DOUGLASS, L.W.; DAHL, G.E.: Predicting growth in Angus bulls: The use of GHRH challenge, insulin-like growth factor-I, and insulinlike growth factor binding proteins. J. Anim. Sci. 78 (2000), 2913-2918

CRONJÉ, P.B.:

Nutrient-gene interactions: future potential and applications. In Ruminant physiology: digestion, metabolism, growth and reproduction (Ed. P. Cronje). CAB International, Wallingford, UK, 2000, p. $409-422$

CRONJÉ, P.B.; JAGER, de M.; VLOK, E.:

Role of insulin sensivity in genotype-nutrition interactions during lactation. S. Afr. J. Anim. Sci. 29 (ISRP) (1999), 303-305

DERNO, M.; LÖHRKE, B.; JENTSCH, W.; MATTHES, H.-D.:

Effect of $\alpha 2$-adrenergic stimulation and feeding on heat production of growing bulls. (Ed. K. J. MCCRACKEN, E. F. UNSWORT and A. R. G. WYLIE). CAB International, Wallingford, UK, 1998, p. 151-154

EVERETT, L.A.; GLASER, B.; BECK, J.C.; IDOL, J.R.; BUCHS, A.; HEYMAN, M.; ADAWI, F.; HAZANI, E.; NASSIR, E.; BAXEVANIS, A.D.; SHEFFIELD, V.C.; GREEN, E.D.:

Pendred syndrome is caused by mutations in a putative sulphate transporter gene (PDS). Nat. Genet. 17 (1997), 411-422

FALCONER, D.S.; MACKAY, T.F.C.:

Introduction to quantitative genetics. Longman Group Ltd 1996

FERREL, C.L.; JENKINS, T.G.:

Body composition and energy utilization by steers of diverse genotypes fed a high-concentrate diet during the finishing period: II. Angus, boran, brahman, hereford, and tuli sires. J. Anim. Sci. 76 (1998), 647-657

FORREST, R.J.:

A comparison of birth growth and carcass characteristics between Holstein-Friesian steers and Charolais x Holstein (F1) crossbreds. Can. J. Anim. Sci. 57 (1977), 713-718

GIESECKE, D.; STANGASSINGER, M.; THEVIS, W.:

Insulinresistenz, Insulinclearance und Lipolyse bei normalen und fetten Kühen. Fortschritte d. Tierphysiol., u. Tierernährg. Nr. 18 (1987a), 57-69 
GIESECKE, D.; STANGASSINGER, M.; VEITINGER W.:

Plasma-Insulin und Insulinantwort bei Kühen mit hoher Milchleistung. Fortschritte d. Tierphysiol., u. Tierernährg. Nr. 18 (1987b), 20-30

GONNEWORDENE, L.:

Selection of beef cattle breeds, Adapted from Alberta Agriculture Beef Herd Management Reference Binder and Study Guide - 201, 1996, http://www.agric.gov.ab.ca/livestock/beef/breeds1.html

GROBET, L.; MARTIN, L.J.R.; PONCELET, D.; PIROTTIN, D.; BROUWERS, B.; RIQUET, J.; SCHOEBERLEIN, A.; DUNNER, S.; MENISSIER, F.; MASSABANDA, J.; FRIES, R.; HANSET, R.; GEORGES, M.:

A deletion in the bovine myostatin gene causes the double- muscled phenotype in cattle. Nat. Genet. 17 (1997), 71-74

GRISART, B.; COPPIETERS, W.; FARNIR, F.; KARIM, L.; FORD, C.; BERZI, P.; CAMBISANO, N.; MNI, M.; REID, S.; SIMON, P.; SPELMAN, R.; GEORGES, M.; SNELL, R.:

Positional Candidate Cloning of a QTL in Dairy Cattle: Identification of a Missense Mutation in the Bovine DGAT1 Gene with Major Effect on Milk Yield and Composition. Genome Res. 12 (2002), 222231

GUIARD, V.; TEUSCHER, F.:

Planning of Intercross Experiments analysed by means of the Regression Model of Haley and Knott. Biometrical Journal, (submitted)

HALEY, C.S.; KNOTT, S.A.:

A simple regression method for mapping quantitative trait loci in line crosses using flanking markers. Heredity 69 (1992), 315-324

HOCQUETTE, J.F.; BAS, P.; BAUCHART; D.; VERMOREL, M.; GEAY, Y.:

Fat partitioning and biochemical characteristics of fatty tissues in relation to plasma metabolites and hormones in normal and double-muscled young growing bulls. Comp. Biochem. Physiol. a Mol. Integr. Physiol. 122 (1999), 127-138

INRA,

Tables de L'Alimentation des Bovins Ovins \& Caprins, Institut National De La Recherche Agronomique, Paris, 1988 (ISBN: 2-7380-0072-X)

ISTASSE, L.; VAN EENAEME, C.; EVRARD, P.; GABRIEL, A.; BALDWIN, P.; MAGHUIN-ROGISTER, G.; BIENFAIT, J.M.:

Animal performance, plasma hormones and metabolites in Holstein and Belgian Blue growing-fattening bulls. J. Anim. Sci. 68 (1990), 2666-2673

KIDDY, C.A.:

A review of research on genetic variation in physiological characteristics related to performance in dairy cattle. J. Dairy Sci. 62 (1979), 818-824

KNOTT, S.A.; MARKLUND, L.; HALEY, C.S.; ANDERSSON, K.; DAVIES, W.; ELLEGREN, H.;

FREDHOLM, M.; HANSSON, I.; HOYHEIM, B.; LUNDSTROM, K.; MOLLER, M.; ANDERSSON, L.:

Multiple marker mapping of quantitative trait loci in a cross between outbred wild boar and large white pigs. Genetics 149 (1998), 1069-1080

KOBAYASHI, Y.; VANDEHAAR, M.J.; TUCKER, H.A.; SHARMA, B.K.; LUCY, M.C.:

Expression of growth hormone receptor $1 \mathrm{~A}$ messenger ribonucleic acid in liver of dairy cows during lactation and after administration of recombinant bovine somatotropin. J. Dairy Sci. 82 (1999), 19101916

KOUDANDE, O.D.; IRAQI, F.; THOMSON, P.C.; TEALE, A.J.; VAN ARENDONK, J.A.M.:

Strategies to optimize marker-assisted introgression of multiple unlinked QTL. Mamm. Genome 11 (2000), 145-150

KÜHN, CH.; FREYER, G.; WEIKARD, R.; GOLDAMMER, T.; SCHWERIN, M.:

Detection of QTL for milk production traits in cattle by application of a specifically developed marker map of BTA6. Anim. Genet. 30 (1999), 333-340

LANDER, E.S.; BOTSTEIN, D.:

Mapping mendelian factors underlying quantitative traits using RFLP linkage maps. Genetics 121 (1989) 1, 185-199

LEBRET, B.; LE ROY, P.; MONIN, G.; LEFAUCHEUR, L.; CARITEZ, J.C.; TALMANT, A.; ELSEN, J.M.; SELLIER, P.:

Influence of the three RN genotypes on chemical composition, enzyme activities, and myofiber characteristics of porcine skeletal muscle. J. Anim. Sci. 77 (1999), 1482-1489

MANDELL, I.B.; GULLETT, E.A.; WILTON, J.W.; ALLEN, O.B.; OSBORNE, V.R.:

Effects of diet, breed and slaughter endpoint on growth performance, carcass composition and beef quality traits in Limousin and Charolais steers. Can. J. Anim. Sci. 77 (1997), 23-32 
MILAN, D.; JEON, J.T.; LOOFT, C.; AMARGER, V.; ROBIC, A.; THELANDER, M.; ROGEL-GAILLARD, C.; PAUL, S.; IANNUCCELLI, N.; RASK, L.; RONNE, H.; LUNDSTROM, K; REINSCH; N.; GELLIN, J.; KALM, E.; LE ROY, P.; CHARDON, P.; ANDERSSON, L.:

A mutation in PRKAG3 associated with excess glycogen content in pig skeletal muscle. Science $\mathbf{2 8 8}$ (2000), 1248-1251

MÜLLER, U.; LEUCHT, W.; REINECKE, P.; DALLE, T.:

Züchtungsbiologische Bewertung der Leistungsselektion beim Milchrind. Arch. Tierz., Dummerstorf 42 (1999) 1, 33-44

PATERSON, A.H.; DAMON, S.; HEWITT, J.D.; ZAMIR, D.; RABINOWITCH, H.D.; LINCOLN, S.E.; LANDER, E.S.; TANKSLEY, S.D.:

Mendelian factors underlying quantitative traits in tomato: comparison accross species, generations and environments. Genetics 127 (1991), 181-197

PATERSON, A.H.; DEVERNA, J.W.; LANINI, B.; TANKSLEY, S.D.:

Fine mapping of quantitative trait loci using selected overlapping recombination chromosomes, in an interspecies cross of tomato. Genetics 124 (1990), 735-742

PETERFY, M.; PHAN, J.; XU, P.; REUE, K.:

Lipodystrophy in the fld mouse results from mutation of a new gene encoding a nuclear protein, lipin. Nat. Genet. 27 (2001), 121-124

SAMBRAUS, H.H.:

Atlas der Nutztierrassen, Stuttgart, Ulmer, 1989

TAI, T.H.; DAHLBECK, D.; CLARK, E.T.; GAJIWALA, P.; PASION, R.; WHALEN, M.C.; STALL, R.E.; STASKAWICZ, B.J.:

Expression of the Bs2 pepper gene confers resistance to bacterial spot disease in tomato. Proc. Natl. Acad. Sci. (USA) 23 (1999), 14153-14158

TAYLOR, ST.C.S.; THIESSEN, R.B.; MURRAY, J.:

Inter-breed relationship of maintenance efficiency to milk yield in cattle. J. Anim. Prod. 43 (1986), 3761

WYLIE, A.R.G.; McGRATTAN, P.D.; NELSON, J.:

Insulin receptor characteristics in ruminant tissues: effects of breed, sex and stage of development. In: Energy metabolism of farm animals. (Ed. K. J. MCCRACKEN, E. F. UNSWORT and A. R. G. WYLIE). CAB International, Wallingford, UK, 1998, p. 111-114

Received: 2001-05-31

Accepted: 2002-06-20

Authors address

Dr. CHRISTA KÜHN, Dr. OLAF BELLMANN, Dr. JÜRGEN VOIGT,

Dr. JOCHEN WEGNER, Dr. VOLKER GUIARD ${ }^{1}$, Prof. Dr. KLAUS ENDER

Research Institute for the Biology of Farm Animals

Wilhelm-Stahl-Allee 2

D-18196 Dummerstorf

Germany

\footnotetext{
${ }^{1}$ corresponding author
} 